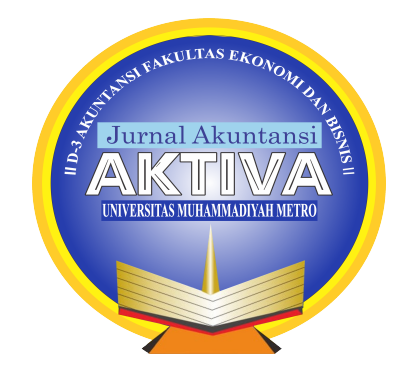

Jurnal Akuntansi AKTIVA, Vol 1, No 1, April 2020

\title{
PENGARUH MANFAAT, KEMUDAHAN DAN KEAMANAN TERHADAP MINAT PEMAKAIAN FINANCIAL TECHNOLOGY PADA APLIKASI OVO SEBAGAI DIGITAL PAYMENT (Study Kasus Mahasiswa FEB Universitas Muhammadiyah Metro)
}

\author{
${ }^{1}$ Widi Yanto, ${ }^{2}$ Ery Baskoro ${ }^{3}$ Fitriani \\ Universitas Muhammadiyah Metro, Jl. Ki Hajar Dewantara, 34111, Lampung, Indonesia \\ Universitas Muhammadiyah Metro, Jl. Ki Hajar Dewantara, 34111, Lampung, Indonesia \\ Universitas Muhammadiyah Metro, Jl. Ki Hajar Dewantara, 34111, Lampung, Indonesia \\ Email:widiyanto@gmail.com, fitriasrin2606@gmail.com
}

\begin{abstract}
This study aims to obtain data and find out the positive effect of benefits, convenience and security on the interest in using financial technology in OVO applications as a digital payment study in the case of FEB students at the Muhammadiyah Metro University. With the technique of sampling, namely with accedental sampling with a sampling time of 30 days to get as many as 68 samples. In this study the method used is libeary research and field research, namely library research, observation, interviews, correspondence, and questionnaires. In this study the analytical tool used is multiple linear regression analysis, to determine the dependent and independent variables with the SPSS V16 For Windows program. The results of research conducted by researchers show that there is an influence on the benefits, convenience and security of the interest in using financial technology in OVO applications as digital payments, based on the analysis results, the data obtained is Fcount 130,280 > 2.75 and is shown by linear regression with the coefficient of determination (R2) 0.859 which means that the interest in financial use in OVO applications is influenced by the benefits, convenience and safety variables of $85.9 \%$ and the remaining $14.1 \%$ is influenced by other factors outside this study.
\end{abstract}

Keywords : Capital Structure, Current Ratio, Size Company, Company Value

\begin{abstract}
ABSTRAK
Penelitian ini bertujuan untuk memperoleh data dan mengetahui pengaruh positif manfaat, kemudahan dan keamanan terhadap minat pemakaian financial technology pafda aplikasi OVO sebagai digital payment study kasusu mahasiswa FEB universitas muhammmadiyah metro. Dengan tehnik pengambilan sampel yaitu dengan accedental sampling dengan waktu pengambilan sampel selama 30 hari di dapatkan sampel sebanyak 68 . Pada penelitian ini metode yang digunakan adalah libeary research dan field research, yaitu penelitian pustaka, observasi, interview, corresponden, dan questionnaire. Dalam penelitian ini alat analisis yang digunakan adalah analisis regresi linier berganda, untuk mengetahui variabel dependen dan independen dengan alat bantu program SPSS V16 For Windows. Hasil penelitain yang telah dilakukan oleh peneliti menunjukan bahwa terdapat pengaruh pada Manfaat, kemudahan dan keamanan terhadap minat pemakaian financial technology pada aplikasi OVO sebagai digital payment, berdasarkan hasil analisis, data yang di peroleh adalah Fhitung 130,280 $>$ 2,75 dan ditunjukan dengan regresi linier dengan koefisien determinasi (R2) 0,859 yang berarti bahwa minat pemakaian financial pada apliaksi OVO di pengaruhi oleh Variabel manfaat, kemudahan dan keamanan sebesar $85,9 \%$ dan sisinya $14,1 \%$ di pengaruhi oleh faktor lain di luar penelitian ini.
\end{abstract}

Kata kunci : manfaat, kemudahan, keamanan, minat pemakaian 


\section{PENDAHULUAN}

Perkembangan teknologi yang semakin cepat telah mempengaruhi kehidupan manusia, kehidupan manusia saat ini sangat dimudahkan dengan teknologi yang ada, sehingga teknologi sudah menjadi hal yang tidak terpisahkan dari kehidupan manusia. Berkembangnya teknologi ditandai dengan munculnya teknologi-teknologi baru di berbagai bidang, seperti bidang pendidikan, ekonomi, politik, kesehatan,dan lain sebagainya. Perkembangnya teknologi di bidang ekonomi, memberikan dampak yang besar pada semua kegiatan keuangan baik itu disektor pemerintah maupun sektor swasta, ini terlihat dengan adanya inovasi baru pada sistem keuangan, sistem keuangan kini mulai menerapkan ekonomi digital untuk memudahkan para pengguna dalam melakukan segala transaksinya. produkproduk ekonomi digital tersebut antara lain mobile bangking, sms bangking, internet bangking, dan fintech. Trend pembayaran menggunakan uang elektronik dengan menggunakan sistem fintech sebagai dompet digital sangat berkembang pesat, keberadaan fintech di dalam sistem keuangan perlahan-lahan akan menggeser metode pembayaran melalui sms bangking, internet bangking atau mobile bangking, karena fintech telah berkembang sangat pesat, kini fintech bisa digunakan untuk membayar keperluan sehari-hari seperti pembayaran tol, pajak, tagihan listrik, bpjs, belanja di mall, membayar barang di online shop, membayar ojek online dan lain-lain.

Fenomena ini akhirnya menimbulkan persaingan yang ketat antara perusahaan-perusahan yang bergerak di bidang dompet digital, baik itu para perusahaan milik swasta ataupun pemerintah, mereka terus berlomba-lomba meluncurkan inovasi baru di bidang fintech untuk menjadi fintech nomer satu di Indonesia. Beberapa aplikasi fintech yang bersaing seperti Dana, OVO, Go-pay, LinkAja, Doku dan lain-lain. Join The Rovolution In Payment atau lebih sering di sebut OVO merupakan aplikasi digital payment yang di dirikan PT visionet internasional pada tahun 2016, OVO adalah aplikasi smart yang memberikan layanan pembayaran dan transaksi secara online. Untuk memiliki aplikasi OVO cukup mudah, hanya dengan mendownload aplikasi OVO di playstore, melengkapi identitas diri, dan mengisi saldo atau melakukan top up, maka apliaksi OVO sudah bisa digunakan.

Penggunaan OVO di Fakultas Ekonomi Dan Bisnis Universitas Muhammadiyah Metro mencerminkan minat pemakaian OVO sebagai digital payment. Maka berdasarkan dari latar belakang yang telah di uraikan ini penelitian ini di beri judul "Pengaruh Manfaat, Kemudahan Dan Keamanan Terhadap Minat Pemakaian Fintech Pada Aplikasi OVO Sebagai Digital Payment (Study Kasus Mahasiswa FEB Universitas Muhammadiyah Metro)".

\section{KAJIAN TEORITIK}

\section{Pengertian Manajemen Pemasaran}

Menurut Prof. Dr. Sofjan Assauri, S.E., M.B.A. pada buku manajemen pemasaran menyatakan, bahwa manajemen pemasaran merupakan kegiatan penganalisisan, perencanaan, pelaksanaan, dan pengendalian program-program yang di buat untuk membentuk, membangun, dan memelihara, keuntungan dan pertukaran melalui sarana pasar guna mencapai tujuan organisasi (perusahaan) dalam jangka panjang.

1. Manfaat

Menurut Adiyanti (2015) manfaat produk baru yang banyak akan meningkatkan minat pengguna dalam bertransaksi menggunakan fintech, ketika produk baru tersebut sangat bermanfaat dalam penggunaannya di kehidupan sehari-hari, maka akan banyak pengguna yang semakin minat dan tertarik dalam menggunakan produk baru ini. Baik itu fintech yang dikeluarkan swasta ataupun pemerintah.

\section{Kemudahan}

Kemudahan menurut Jogiyanto (2007:115) kemudahan didefinisikan sebagai sejauh mana seseorang percaya bahwa menggunakan suatu teknologi akan bebas dari usaha, kemudahan penggunaan dalah mudah dalam mempelajari, mudah dipahami, simpel dan mudah mengoprasikannya (Jogiyanto, 2007:129).

3. Keamanan 
Keamanan menurut Pratama adalah hal yang mutlak disediakan oleh para pelaku bisnis, baik produk, layanan maupun keduanya, keamanan memberikan kenyamanan pada pengguna (atau dalam hal ini konsumen) dan meningkatkan kepercayaan konsumen (customer trust), yang berujung kepada peningkatan jumlah penjualan (pratama 2015:197).

4. Minat Pemakaian Financial Technology Pada Aplikasi OVO

Menurut (Hartono, 2007:166 dalam Shomad dan Purnomosidhi 2012) minat adalah suatu keinginan seseorang untuk melakukan suatu prilaku tertentu, seseorang akan melakukan sesuatu prilaku jika memiliki keinginan atau minat untuk melakukannya. Ketika seseorang menilai bahwa sesuatu itu akan memiliki manfaat, maka akan timbul minat pada diri seseorang itu, lalu hal tersebut akan mendatangkan sebuah kepuasan dengan manfaat yang telah diperolehnya, maka ini berarti minat berhubungan dengan nilai-nilai yang membuat seseorang mempunyai pilihan dalam hidupnya.

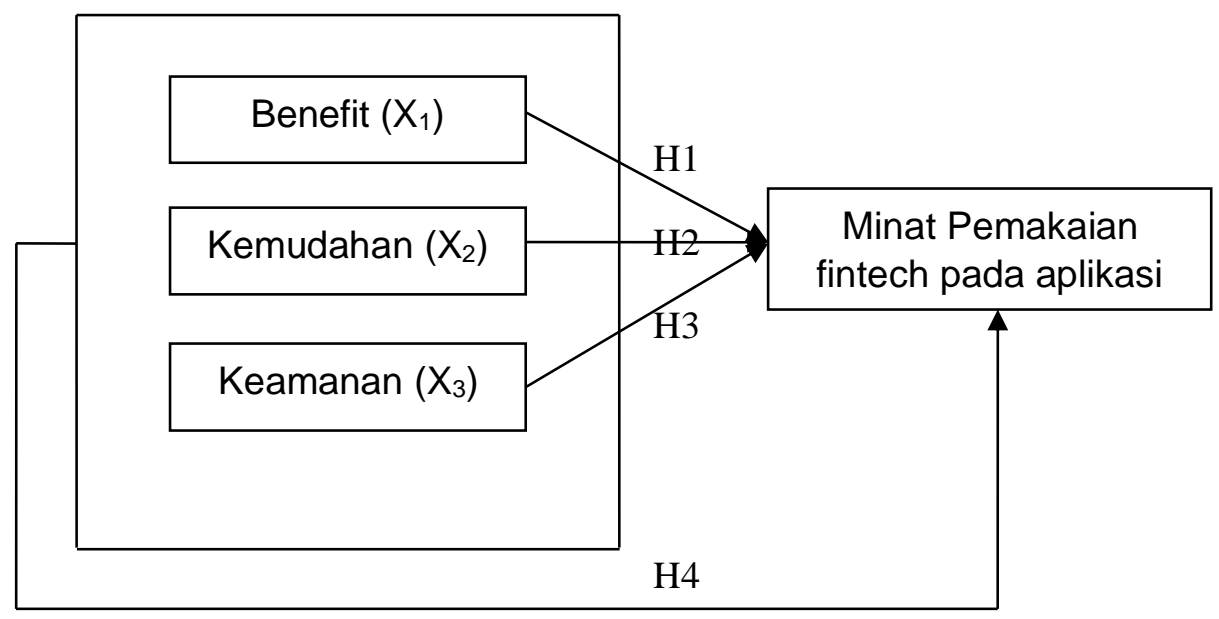

GAMBAR 2.1 Kerangka Pemikiran

Hipotesis Penelitian

Berdasarkan kerangka pemikiran yang telah dijelaskan sebelumnya, maka terdapat hipotesis pada penelitian ini yang bisa dirumuskan sebgai berikut :

H1 = Manfaat (X1) berpengaruh positf terhadap minat pemakaian fintech pada aplikasi OVO sebagai digital payment $(\mathrm{Y})$

$\mathrm{H} 2$ = Kemudahan $(\mathrm{X} 2)$ berpengaruh positf terhadap minat pemakaian fintech pada aplikasi OVO sebagai digital payment $(\mathrm{Y})$

H3 = Keamanan (X3) berpengaruh positf terhadap minat pemakaian fintech pada aplikasi OVO sebagai digital payment (Y)

H4 = Manfaat (X1), Kemudahan (X2), keamanan (X3) berpengaruh positf terhadap minat pemakaian fintech pada aplikasi OVO sebagai digital payment $(\mathrm{Y})$

\section{METODE PENELITIAN}

A. Jenis Penelitian

Jenis penelitian yang digunakan adalah penelitian kualitatif dan kuantitatif yaitu suatu proses menemukan hasil penelitiannya yang numerik dan menekankan proses penelitian pada pengukuran yang objektif, dengan menggunakan data statistik,

B. Objek Dan Tempat Penelitian

Dalam Objek penelitian skripsi ini membahas tentang Manfaat, kemudahan, keamanan, dan minat pemakaian fintech pada aplikasi OVO dengan study kasus mahasisa Fakultas Ekonomi Dan Bisnis Universitas Muhammadiyah Metro, kegiatan penelitian ini dilakukan di lingkungan Universitas Muhammadiyah Metro Kampus 1 Jln. Kihajar Dewantara No.115 Iringmulyo Kota Metro. 


\section{Metode Penelitian}

Metode yang akan digunakan dalam penelitian ini adalah metode explanatori research, menurut Umar (1999:36) penelitian eksplanatori (explanatori research) adalah penelitian yang bertujuan untuk menganalisis hubungan-hubungan antar satu variabel dengan variabel lainnya. Dengan menggunakan program SPSS (statistical package for the social science) 16.0 sebagai alat untuk metode analisis data pada penelitian ini.

\section{HASIL DAN PEMBAHASAN}

\section{Gambaran Umum Objek Penelitian}

\section{Sejarah Singkat OVO}

Join The Rovolution In Payment, point and priority atau lebih sering di sebut OVO, merupakan layanan dompet digital smart financial apps yang menawarkan berbagai kemudahan transaksi hanya dengan menggunakan smart phone yang di miliki disejumlah mitra OVO. Perusahaan ini merupakan besutan Grup Lippo yaitu LippoX, OVO pertama kali diluncurkan Pada maret 2017 dibawah naungan PT. visionet Internasional.

\section{Struktur organisasi OVO}

Struktur organisasi adalah sebuah susunan berbagai komponen atau unit kerja dalam sebuah organisasi yang ada di sebuah perusahaan, yang membuat terbaginya fungsi atau kegiatan. Dan di bawah ini adalah struktur organisasi PT Visonet Internasional.

\section{B. Hasil Penelitian}

Berdasarkan kisi-kisi instrumen penelitian, maka dibuat instrumen penelitian berupa kuesioner yang bertujuan untuk mencari data yang diinginkan dalam penelitian ini. Dengan banyak butir pertanyaan dalam vriabel manfaat (X1) sebanyak 20 item, varibale kemudahan (X2) sebanyak 20 item, variabel keamanan (X3) sebanyak 20 item dan pada variabel minat pemakaian fintech pada aplikasi OVO sebanyak 20 item.

1. Pengujian Persyaratan Analisis

a. Uji Normalitas

Uji normalitas dilakukan dengan tujuan untuk mengetahui apakah populasi data berdistribusi normal atau tidak. Uji ini biasanya digunakan untuk mengukur data yang berskala ordinal, interval ataupun rasio.

\section{a. Uji Normalitas}

Uji normalitas dilakukan dengan tujuan untuk mengetahui apakah populasi data berdistribusi normal atau tidak. Uji ini biasanya digunakan untuk mengukur data yang berskala ordinal, interval ataupun rasio.

Tabel 4.1 Hasil Uji Normalitas

\begin{tabular}{|l|l|l|l|}
\hline Variable & Nilai a & Nilai siq & Interpretasi \\
\hline $\mathrm{X}_{1}$ & 0,05 & 0,200 & Normal \\
\hline $\mathrm{X}_{2}$ & 0,05 & 0,200 & Normal \\
\hline $\mathrm{X}_{3}$ & 0,05 & 0,200 & Normal \\
\hline $\mathrm{Y}$ & 0,05 & 0,200 & Normal \\
\hline
\end{tabular}

Sumber. Hasil pengolahan data menggunakan spss versi 16

\section{b. Uji Linieritas}


Uji linieritas dilakukan dengan tujuan kepentingan ketetapan estimasi. Setiap estimasi biasanya diharapkan pada suatu kepastian atau kejelasan sehingga kesimpulan yang dihasilkan memiliki akurasi yang tinggi.

Tabel 4.2 ANOVA Linieritas Y Atas $X_{1}$

ANOVA Table

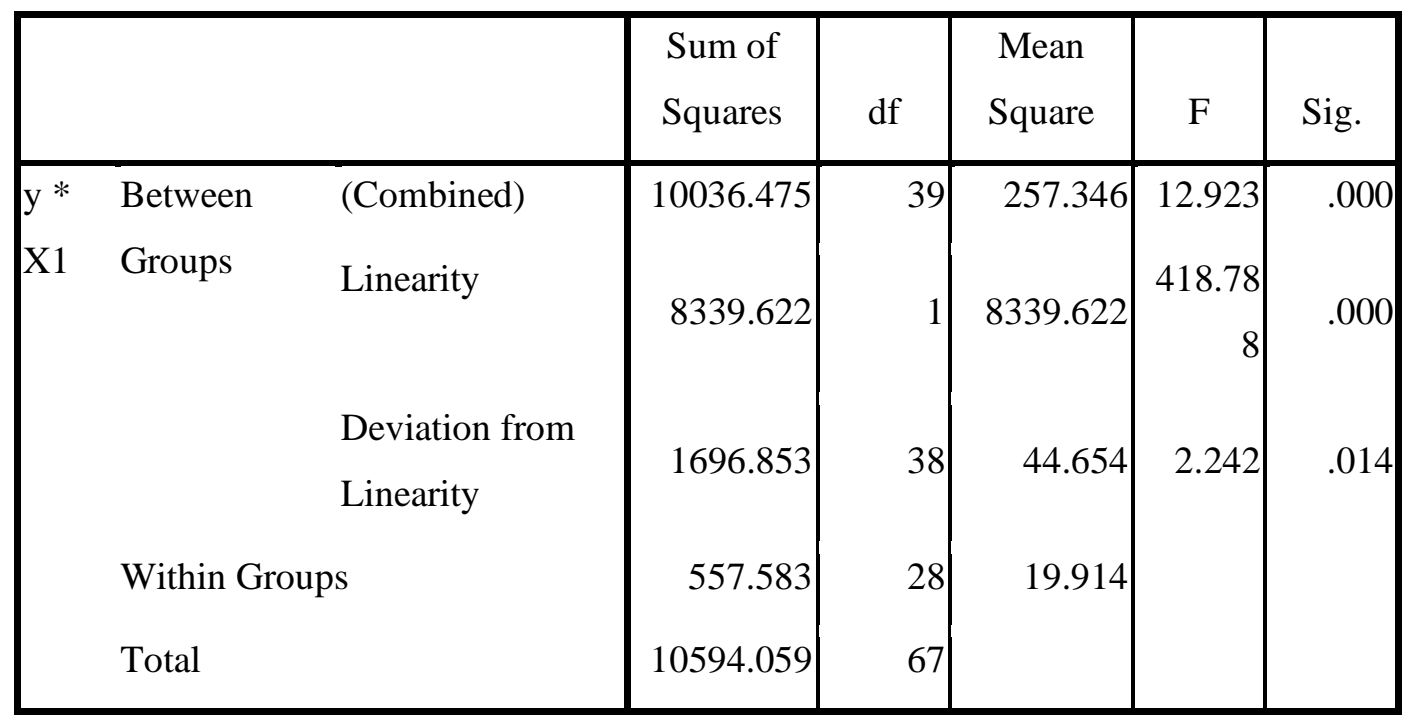

Hasil uji linieritas pada penelitian ini dapat dilihat dari data output ANOVA. Dari tabel di atas dapat di ketahui bahwa nilai signifikansi pada Deviantion From Linearity sebesar 0,014 karena nilai signifikan kurang dari 0,05 maka dapat disimpulkan bahwa antara variabel minat pemakaian fintech OVO $(\mathrm{Y})$ dan manfaat $\left(\mathrm{X}_{1}\right)$ terdapat hubungan yang linier.

Tabel 4.3 ANOVA Linieritas Y Atas X2

ANOVA Table

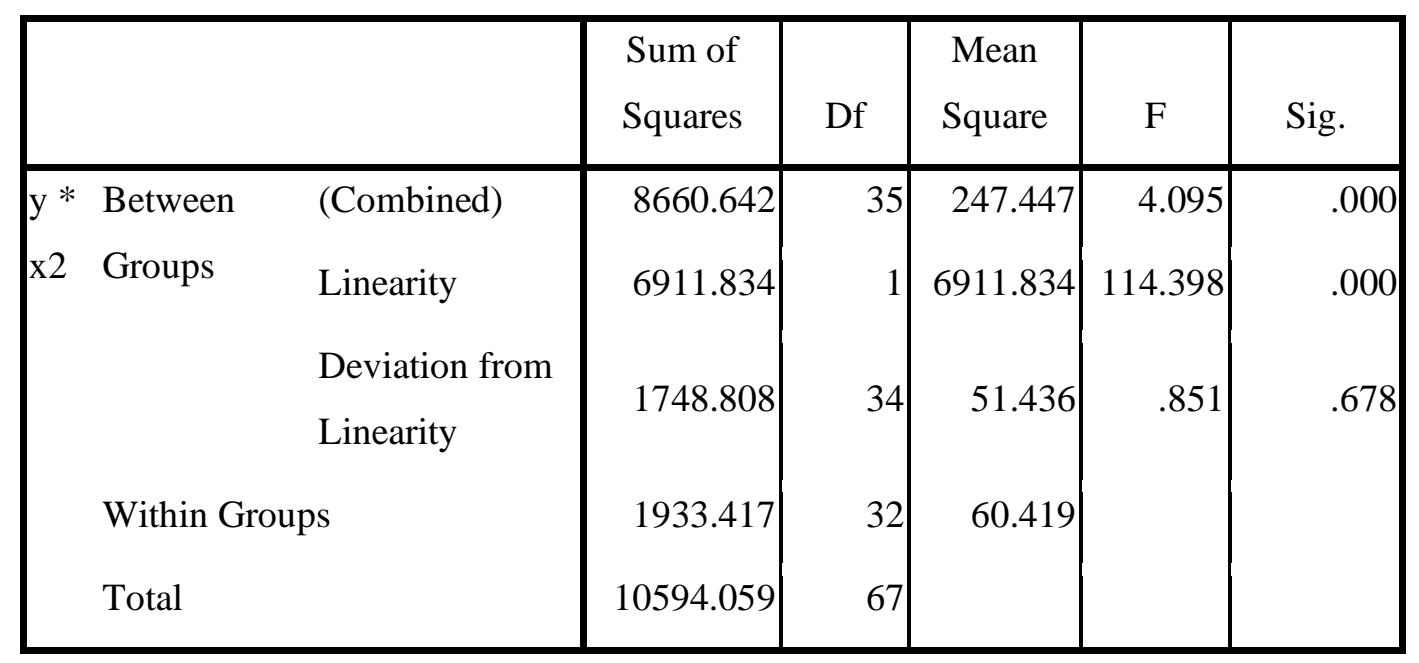

Hasil uji linieritas pada penelitian ini dapat dilihat dari data output ANOVA. Dari tabel di atas dapat di ketahui bahwa nilai signifikansi pada Deviantion From Linearity sebesar 0,678 karena nilai 
signifikan lebih dari 0,05 maka dapat disimpulkan bahwa antara variabel minat pemakaian fintech OVO (Y) dan kemudahan $\left(\mathrm{X}_{2}\right)$ terdapat hubungan yang linier.

Tabel 4.4 ANOVA Linieritas Y Atas X3

ANOVA Table

\begin{tabular}{|c|c|c|c|c|c|c|c|}
\hline & & & $\begin{array}{l}\text { Sum of } \\
\text { Squares }\end{array}$ & $\mathrm{df}$ & $\begin{array}{l}\text { Mean } \\
\text { Square }\end{array}$ & $\mathrm{F}$ & Sig. \\
\hline \multirow{6}{*}{ x3 } & Between & (Combined) & 9383.725 & 38 & 246.940 & 5.917 & .000 \\
\hline & Groups & Linearity & 8125.344 & 1 & 8125.344 & 194.686 & .000 \\
\hline & & Deviation from & $1258 \quad 380$ & $27 .>$ & 34010 & 815 & 724 \\
\hline & & Linearity & & & & & \\
\hline & \multicolumn{2}{|c|}{ Within Groups } & 1210.333 & 29 & 41.736 & & \\
\hline & \multicolumn{2}{|l|}{ Total } & 10594.059 & 67 & & & \\
\hline
\end{tabular}

Hasil uji linieritas pada penelitian ini dapat dilihat dari data output ANOVA. Dari tabel di atas dapat di ketahui bahwa nilai signifikansi pada Deviantion From Linearity sebesar 0,724 karena nilai signifikan lebih dari 0,05 maka dapat disimpulkan bahwa antara variabel minat pemakaian fintech OVO $(\mathrm{Y})$ dan keamanan $\left(\mathrm{X}_{3}\right)$ terdapat hubungan yang linier.

\section{c. Uji Homogenitas}

Uji homogenitas dilakukan dengan tujuan untuk menghitung bahwa data sampel dari populasi yang mempunyai varian yang homogen. Adapun hasil homogenitas yang telah dilakukan sebagai berikut :

\section{Uji homogenitas varian $Y$ atas $X_{1}$}

Tabel 4.5 Hasil Uji Homogenitas Linieritas $Y$ Atas $X_{1}$

\section{Test of Homogeneity of Variances}

Y

\begin{tabular}{|l|l|l|l|}
\hline $\begin{array}{l}\text { Levene } \\
\text { Statistic }\end{array}$ & df1 & df2 & Sig. \\
\hline 1.959 & 15 & 28 & .060 \\
\hline
\end{tabular}

Berdasarkan uji homogenitas yang telah dilakukan, hasil tabel 4.2 menunjukan bahwa $\mathrm{Y}$ atas $\mathrm{X}_{1}$, adalah sig $0,060>0,05$, sehingga skor pada variabel manfaat $\left(\mathrm{X}_{1}\right)$ terhadap minat menggunakan fintech OVO $(\mathrm{Y})$ berasal dari populasi yang homogen.

2. Uji homogenitas varian $Y$ atas $X_{2}$

Tabel 4.6 Hasil Uji Homogenitas Linieritas $Y$ Atas $X_{2}$ 
Test of Homogeneity of Variances

$\mathrm{Y}$

\begin{tabular}{|r|r|r|r|}
\hline $\begin{array}{l}\text { Levene } \\
\text { Statistic }\end{array}$ & \multicolumn{1}{|c|}{ df1 } & \multicolumn{1}{c|}{ df2 } & \multicolumn{1}{c|}{ Sig. } \\
\hline 2.483 & 21 & 32 & .010 \\
\hline
\end{tabular}

Berdasarkan uji homogenitas yang telah dilakukan, hasil tabel 4.2 menunjukan bahwa $\mathrm{Y}$ atas $\mathrm{X}_{1}$, adalah sig $0,010<0,05$, sehingga skor pada variabel kemudahan $\left(\mathrm{X}_{2}\right)$ terhadap minat menggunakan fintech OVO (Y) berasal dari populasi yang tidak homogen.

3. Uji homogenitas varian $Y$ atas $X_{3}$

Tabel 4.7 Hasil Uji Homogenitas Linieritas $Y$ Atas $X_{3}$

Test of Homogeneity of Variances

$\mathrm{Y}$

\begin{tabular}{|r|r|r|r|}
\hline $\begin{array}{l}\text { Levene } \\
\text { Statistic }\end{array}$ & df1 & \multicolumn{1}{c|}{ df2 } & \multicolumn{1}{c|}{ Sig. } \\
\hline 2.415 & 19 & 29 & .016 \\
\hline
\end{tabular}

Berdasarkan uji homogenitas yang telah dilakukan, hasil tabel 4.2 menunjukan bahwa $\mathrm{Y}$ atas $\mathrm{X}_{1}$, adalah sig $0,016<0,05$, sehingga skor pada variabel keamanan $\left(\mathrm{X}_{3}\right)$ terhadap minat menggunakan fintech OVO berasal dari populasi yang tidak homogen.

\section{Pengujian Model Analisis}

a. Analisis Regresi Linier Berganda

Tabel 4.12 Hasil Uji Regresi Linier Berganda

Coefficients $^{\mathbf{a}}$

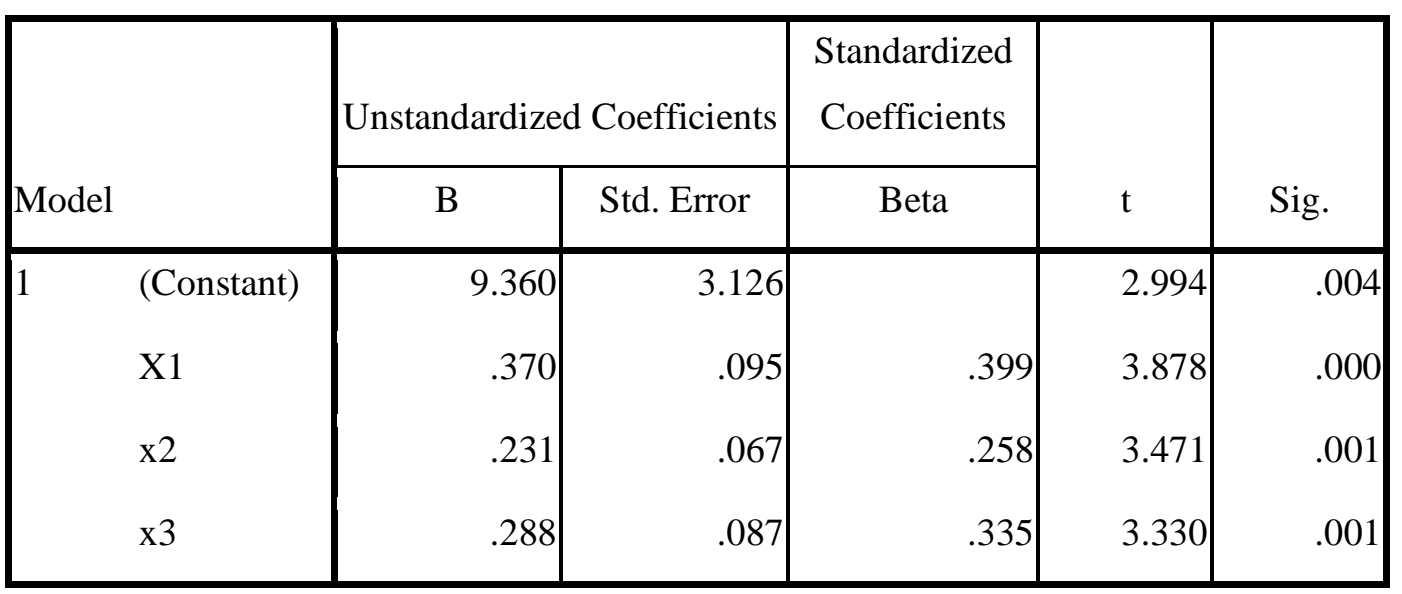

a. Dependent Variable: y

Berdasarkan uji yang telah dilakukan, pengolahan data pada tabel 4.12 dapat dirumuskan dengan model persamaan regresi linier berganda sebagai berikut :

$\mathrm{Y}=\alpha+\beta 1 \mathrm{X} 1+\beta 2 \mathrm{X} 2+\beta 3 \mathrm{X} 3+\mathrm{e}$

$\mathrm{Y}=9,301+0,347 \mathrm{X} 1+0,189 \mathrm{X} 2+0,355 \mathrm{X} 3+\mathrm{e}$

b. Uji Parsial (uji-t)

$\mathbf{1 0 2} \mid$ Jurnal Akuntansi AKTIVA 
Pada uji statistik t ini pada dasarnya akan menunjukan seberapa jauh pengaruh satu variabel independen secara individual, serta akan menerangkan juga varian variabel dependen. Uji t dengan tingkat signifikasi sebesar $(\alpha)=0,05$ yaitu dengan membandingkan nilai $t$ hitung dan $t$ tabel, apabila $t$ tabel $<\mathrm{t}$ hitung maka, Ho ditolak dan Ha diterima, sedangkan apabila $\mathrm{t}$ tabel $>\mathrm{t}$ hitung maka Ho diterima dan Ha ditolak. Maka dapat di simpulkan bahwa :

1. Manfaat $\left(\mathrm{X}_{1}\right)$

Pada variabel manfaat nilai $t_{\text {hitung }}$ sebesar 3.878 sedangkan $t$ tabel memiliki nilai 1,995 dengan demikian nilai $t_{\text {hitung }}(3.878)>\mathrm{t}_{\text {tabel }}(1,995)$ dengan tingkat signifikansi sebesar $0,000<0,05$. Maka ini menunjukan bahwa manfaat berpengaruh positif dan signifikan terhadap minat pemakaian financial technology pada aplikasi OVO di Fakultas Ekonomi Dan Bisnis Universitas Muhammadiyah Metro, artinya jika variabel manfaat ditingkatkan maka minat pemakaian akan meningkat. Maka dapat disimpulkan bahwa Ho ditolak dan Ha diterima.

2. kemudahan $\left(\mathrm{X}_{2}\right)$

Pada variabel kemudahan nilai $t_{\text {hitung }}$ sebesar 3.471 sedangkan $t_{\text {tabel }}$ memiliki nilai 1,995 dengan demikian nilai $t_{\text {hitung }}(3.471)>t_{\text {tabel }}(1,995)$ dengan tingkat signifikansi sebesar $0,001<0,05$. Maka ini menunjukan bahwa kemudahan berpengaruh positif dan signifikan minat pemakaian financial technology pada aplikasi OVO di Fakultas Ekonomi Dan Bisnis Universitas Muhammadiyah Metro, artinya jika variabel kemudahan ditingkatkan maka minat pemakaian akan meningkat. Maka dapat disimpulkan bahwa Ho ditolak dan Ha diterima.

3. Keamanan $\left(\mathrm{X}_{3}\right)$

Pada variabel keamanan nilai $t_{\text {hitung }}$ sebesar 3.330 sedangkan $t_{\text {tabel }}$ memiliki nilai 1,995.dengan demikian nilai $t_{\text {hitung }}(3.330)>t_{\text {tabel }}(1,995)$ dengan tingkat signifikansi sebesar $0,001<0,05$. Maka ini menunjukan bahwa keamanan berpengaruh positif dan signifikan terhadap minat pemakaian financial technology pada aplikasi OVO di Fakultas Ekonomi Dan Bisnis Universitas Muhammadiyah Metro, artinya jika variabel keamanan ditingkatkan maka minat pemakaian akan meningkat. Maka dapat disimpulkan bahwa Ho ditolak dan Ha diterima.

\section{Uji Simultan (uji-F)}

Pengambilan keputusan dengan tingkat signifikan $(\alpha)=0,05$ yaitu dengan membandingkan nilai $F_{\text {hitung }}$ dengan $F_{\text {tabel, }}$, apabila $F_{\text {tabel }}>F_{\text {hitung }}$ maka Ho diterima dan Ha ditolak, namun apabila $F_{\text {tabel }}<$ $\mathrm{F}_{\text {hitung }}$ maka Ho ditolak dan Ha diterima. Adapun hasil uji $\mathrm{F}$ yang telah dilakukan adalah sebagai berikut :

Tabel 4.13 Hasil Uji Simultan (UJI-f)

ANOVA $^{b}$

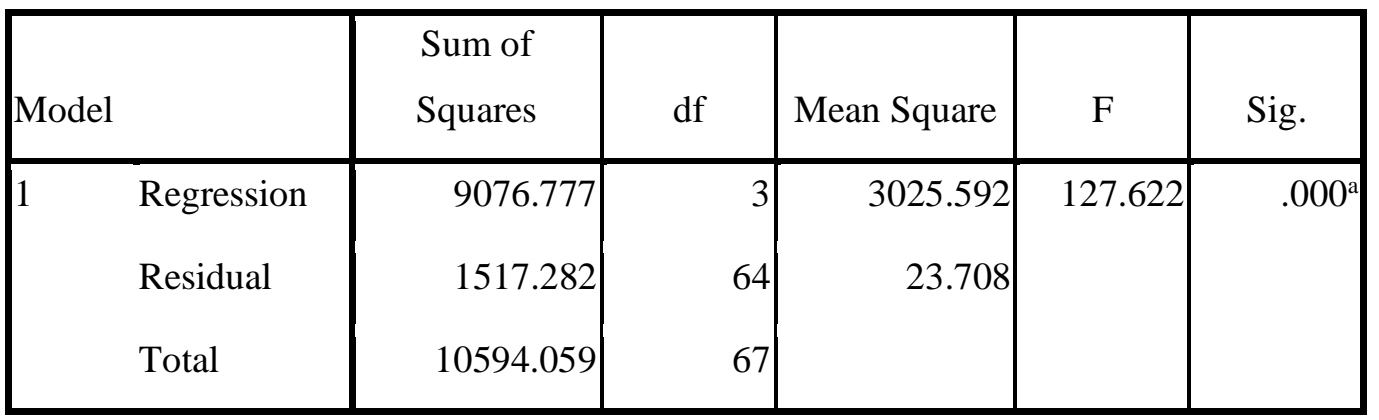

a. Predictors: (Constant), x3, x2, X1

b. Dependent Variable: y

Berdasarkan dari tabel 4.13 menunjukan bahwa variabel manfaat, kemudahan, dan keamanan secara bersamaan berpengaruh positif dan signifikan terhadap minat pemakaian financial technology pada aplikasi OVO di Fakultas Ekonomi Dan Bisnis Universitas Muhammadiyah Metro. Hal ini dapat dilihat pada tabel nilai Fhitung adalah 127,622 lebih besar dari 3 dengan probabilitas 0,000 lebih kecil 
dari 0,05 dan diperoleh nilai Fhitung > Ftabel yaitu dapat dilihat pada tabel $\mathrm{F}$ dengan menggunakan tingkat keyakinan $95 \%$ a $=5 \%$ nilai $\mathrm{d} / \mathrm{f}=3$ dan $\mathrm{d} / \mathrm{f} 2=(\mathrm{n}-\mathrm{k}-1)=68-3-1=64$ maka nilai ftabel adalah sebesar 2,75 dengan demikian diperoleh nilai Fhitung> Ftabel $(127,622>2,75)$ berdasarkan kriteria pengujian hipotesisi makan dapat disimpulkan bahwa ho ditolak dan ha diterima.

\section{d. Uji R2 Determinasi}

Pada uji koefisien determinan menggambarkan seberapa besar kemampuan semua variabel independen dalam menjelaskna varian dari variabel dependennya. Nilai koefisienan determinasi berkisaran antara 0 sampai 1, apabila variabel terkait memiliki nilai koefisien determinasi mendekati 1 artinya pengaruh variabel independen tersebut sangat kuat terhadap variabel dependen, dan sebaliknya jika nilai koefesien determinasi mendekati Omaka pengaruh variabel independen terhadap variabel dependen semakin lemah, adapun hasil uji R2 yang telah dilakukan sebagai berikut :

Tabel 4.14 Hasil R2 Diterminasi Model Summary

\begin{tabular}{|l|r|r|r|r|}
\hline Model & \multicolumn{1}{|c|}{$\mathrm{R}$} & R Square & \multicolumn{1}{c|}{$\begin{array}{c}\text { Adjusted R } \\
\text { Square }\end{array}$} & $\begin{array}{c}\text { Std. Error of } \\
\text { the Estimate }\end{array}$ \\
\hline 1 & $.926^{\mathrm{a}}$ & .857 & .850 & 4.869 \\
\hline
\end{tabular}

a. Predictors: (Constant), x3, x2, X1

Berdasarkan tabel 4.14 di atas, menunjukan bahwa $\mathrm{R}$ square memilki nilai sebesar 0,859 yang berarti $85,7 \%$ variabel manfaat, kemudahan dan keamanan dapat dijelaskan oleh variabel minat pemakaian financial technology pada aplikasi OVO di Fakultas Ekonomi Dan Bisnis Universitas Muhammadiyah Metro. Sedangkan 14,3\% dipengaruhi atau dijelaskan oleh variabel lain yang tidak dibahas dalam penelitian ini.

\section{e. Hipotesis statistik}

Setelah melakukan beberapa pengujian model analisis, kemudian akan dilakukan pengujian hipotesis untuk mengetahui antara variabel memiliki pengaruh positif atau tidak positif. Hasil keputusan seluruh variabel yang di ajukan ialah sebagai berikut :

\section{Manfaat $\left(\mathrm{X}_{1}\right)$ Berpengaruh Positif Dan Signifikan Terhadap Minat Pemakaian Financial}

\section{Technology Pada Aplikasi OVO (Y)}

Hipotesis secara statistik akan dirumuskan sebagai berikut :

Ho: $\beta_{1} \leq 0$

$\mathrm{H}_{1}: \beta_{1} \geq 0$

Berdasarkan hasil perhitungan pengujian hipotesis koefisien $\beta$ dan $t_{\text {hitung }}$ dengan menggunakan spss $\mathrm{v}$ 16 disajikan pada tabel dibawah ini :

Tabel 4.15 Hasil Pengujian Manfaat Pengaruh Positif Dan Signifikan Terhadap Minat Pemakaian Financial Technology Pada Aplikasi OVO

\begin{tabular}{|c|c|c|c|}
\hline Sampel & Koefisien $\boldsymbol{\beta}$ & $\mathbf{t}_{\text {hitung }}$ & $\mathbf{t}_{\text {tabel }}(\boldsymbol{\alpha}=\mathbf{0 , 0 5})$ \\
\hline 68 & 0,370 & 3,878 & 1,995 \\
\hline
\end{tabular}

Sumber. Hasil Pengolahan Data Dengan Menggunakan Spss V16 


\section{Kemudahan (X2) Berpengaruh Positif Dan Signifikan Terhadap Minat Pemakaian Financial Technology Pada Aplikasi OVO (Y)}

Hipotesis secara statistik akan dirumuskan sebagai berikut :

Ho: $\beta \mathrm{X} 2 \leq 0$

$\mathrm{H} 2: \beta \mathrm{X} 2 \geq 0$

Berdasarkan hasil perhitungan pengujian hipotesis koefisien $\beta$ dan thitung dengan menggunakan spss v 16 disajikan pada tabel dibawah ini :

Tabel 4.16 Hasil Pengujian Kemudahan Pengaruh Positif Dan Signifikan Terhadap Minat Pemakaian Financial Technology Pada Aplikasi OVO

\begin{tabular}{|c|c|c|c|}
\hline Sampel & Koefisien $\boldsymbol{\beta}$ & $\mathbf{t}_{\text {hitung }}$ & $\mathbf{t}_{\text {tabel }}(\boldsymbol{\alpha}=\mathbf{0 , 0 5})$ \\
\hline 68 & 0,231 & 3,471 & 1,995 \\
\hline
\end{tabular}

Sumber. Hasil Pengolahan Data Dengan Menggunakan Spss V16

Berdasarkan tabel hasil pengujian diatas menunjukan bahwa koefisien variabel kemudahan terhadap minat pemakaian financial pada aplikasi OVO memiliki nilai $\beta=0,231$ dengan nilai $t_{\text {hitung }}$ 3,471 lebih besar dari nilai $t_{\text {tabel }}(\alpha=0,05)=1,995$, karena $t_{\text {hitung }}>t_{\text {tabel }}$ maka koefisien $\beta$ positif dan signifikan. Maka dari temuan ini dapat disimpulkan bahwa kemudahan $\left(\mathrm{X}_{2}\right)$ berpengaruh positif dan signifikan terhadap minat pemakaian financial technology pada aplikasi OVO (Y).

3.. Keamanan $\left(X_{3}\right)$ Berpengaruh Positif Dan Signifikan Terhadap Minat Pemakaian Financial Technology Pada Aplikasi OVO (Y)

Hipotesis secara statistik akan dirumuskan sebagai berikut :

Ho: $\beta \mathrm{X}_{3} \leq 0$

$\mathrm{H}_{3}: \beta \mathrm{X}_{3} \geq 0$

Berdasarkan hasil perhitungan pengujian hipotesis koefisien $\beta$ dan $t_{\text {hitung }}$ dengan menggunakan spss $v 16$ disajikan pada tabel dibawah ini :

Tabel 4.17 Hasil Pengujian Keamanan Pengaruh Positif Dan Signifikan Terhadap Minat Pemakaian Financial Technology Pada Aplikasi OVO

\begin{tabular}{|c|c|c|c|}
\hline Sampel & Koefisien $\boldsymbol{\beta}$ & $\mathbf{t}_{\text {hitung }}$ & $\mathbf{t}_{\text {tabel }}(\boldsymbol{\alpha}=\mathbf{0 , 0 5})$ \\
\hline 68 & 0,288 & 3,330 & 1,995 \\
\hline
\end{tabular}

Sumber. Hasil Pengolahan Data Dengan Menggunakan Spss V16

Berdasarkan tabel hasil pengujian diatas menunjukan bahwa koefisien variabel keamanan terhadap minat pemakaian financial pada aplikasi OVO memiliki nilai $\beta=0,288$ dengan nilai $t_{\text {hitung }}$ 3,330 lebih besar dari nilai $t_{\text {tabel }}(\alpha=0,05)=1,995$, karena $t_{\text {hitung }}>t_{\text {tabel }}$ maka koefisien $\beta$ positif dan signifikan. Maka dari temuan ini dapat disimpulkan bahwa keamanan $\left(\mathrm{X}_{3}\right)$ berpengaruh positif dan signifikan terhadap minat pemakaian financial technology pada aplikasi OVO (Y).

\section{b. Pembahasan}

Berdasarkan hasil pengujian dan perhitungan secara keseluruhan diatas, maka dapat diuraikan dan dibahas hingga memberikan informasi secara objektif sebagai berikut :

1. Terdapat Pengaruh Yang Positif Dan Signifikan pada Manfaat Terhadap Minat Pemakaian Financial Technology Pada Aplikasi OVO 
Berdasarkan uraian diatas menunjukan bahwa hasil penelitian pada variabel manfaat $\left(\mathrm{X}_{1}\right)$ memiliki pengaruh yang positif dan signifikan terhadap minat pemakaian financial technology pada aplikasi OVO. Ini terlihat dari nilai $\beta=0,370$ nilai $t_{\text {hitung }} 3,878$ lebih besar dari nilai $t_{\text {tabel }}(\alpha=0,05)=$ 1,995 , karena $t_{\text {hitung }}>t_{\text {tabel }}$ maka koefisien $\beta$ positif dan signifikan. Hal ini menunjukan bahwa manfaat produk yang diberikan OVO membuat kesan dan penilaian konsumen terhadap financial technology pada aplikasi OVO sangat baik, sehingga membuat konsumen ahirnya berminat menggunakan produk OVO sebagai dompet digital.

Terdapat Pengaruh Yang Positif Dan Signifikan pada kemudahan Terhadap Minat Pemakaian Financial Technology Pada Aplikasi OVO

Berdasarkan uraian diatas menunjukan bahwa hasil penelitian pada variabel kemudahan $\left(\mathrm{X}_{2}\right)$ memiliki pengaruh yang positif dan signifikan terhadap minat pemakaian financial technology pada aplikasi OVO. Ini terlihat dari nilai $\beta=0,231$ dengan nilai $t_{\text {hitung }} 3,471$ lebih besar dari nilai $t_{\text {tabel }}$ $(\alpha=0,05)=1,995$, karena $t_{\text {hitung }}>t_{\text {tabel }}$ maka koefisien $\beta$ positif dan signifikan. Hal ini menunjukan bahwa konsumen telah merasakan dan menilai kemudahan dalam mengoprasikan OVO dan kemudahan dalam bertransaksi sangat baik, sehingga membuat konsumen ahirnya berminat menggunakan produk OVO sebagai dompet digital.

\section{Terdapat Pengaruh Yang Positif Dan Signifikan pada keamanan Terhadap Minat Pemakaian Financial Technology Pada Aplikasi OVO}

Berdasarkan uraian diatas menunjukan bahwa hasil penelitian pada variabel keamanan $\left(\mathrm{X}_{3}\right)$ memiliki pengaruh yang positif dan signifikan terhadap minat pemakaian financial technology pada aplikasi OVO. Ini terlihat dari nilai $\beta=0,288$ dengan nilai $t_{\text {hitung }} 3,330$ lebih besar dari nilai tabel $(\alpha=0,05)=1,995$, karena $t_{\text {hitung }}>t_{\text {tabel }}$ maka koefisien $\beta$ positif dan signifikan. Hal ini menunjukan bahwa konsumen telah merasakan dan menilai bahwa sistem keamanan dan keamanan bertransaksi pada aplikasi OVO sangat baik, sehingga membuat konsumen ahirnya berminat menggunakan produk OVO sebagai dompet digital.

\section{Terdapat Pengaruh Yang Positif Dan Signifikan secara bersama-sama Manfaat, kemudahan dan keamanan Terhadap Minat Pemakaian Financial Technology Pada Aplikasi OVO}

Berdasarkan uraian diatas menunjukan bahwa hasil penelitian pada variabel manfaat $\left(\mathrm{X}_{1}\right)$, kemudahan $\left(\mathrm{X}_{2}\right)$, dan keamanan $\left(\mathrm{X}_{3}\right)$ secara bersamaan memiliki pengaruh yang positif dan signifikan terhadap minat pemakaian financial technology pada aplikasi OVO. Hal ini manfaat produk yang diberikan OVO, kemudahan dalam mengoprasikan OVO dan kemudahan dalam bertransaksi, sistem keamanan dan keamanan bertransaksi pada aplikasi OVO sangat baik, sehingga membuat konsumen ahirnya berminat menggunakan produk OVO sebagai dompet digital.

\section{KESIMPULAN DAN SARAN}

\section{A. Kesimpulan}

Berdasarkan analisis data yang telah dibahas dapat disimpulkan sebagai berikut :

1. Variabel manfaat $\left(\mathrm{X}_{1}\right)$ memiliki pengaruh yang positif terhadap minat pemakaian financial technology pada aplikasi OVO. Ini terlihat dari nilai $\beta=0,370$ nilai $t_{\text {hitung }} 3,878$ lebih besar dari nilai $t_{\text {tabel }}(\alpha=0,05)=1,995$, karena $t_{\text {hitung }}>t_{\text {tabel }}$ maka koefisien $\beta$ positif dan signifikan. Hal ini menunjukan bahwa manfaat produk yang diberikan OVO membuat kesan dan penilaian konsumen terhadap financial technology pada aplikasi OVO sangat baik, sehingga membuat konsumen ahirnya berminat menggunakan produk OVO sebagai dompet digital..

2. Variabel kemudahan $\left(\mathrm{X}_{2}\right)$ memiliki pengaruh yang positif terhadap minat pemakaian financial technology pada aplikasi OVO. Ini terlihat dari nilai $\beta=0,231$ dengan nilai $t_{\text {hitung }}$ 3,471 lebih besar dari nilai $t_{\text {tabel }}(\alpha=0,05)=1,995$, karena $t_{\text {hitung }}>t_{\text {tabel }}$ maka koefisien $\beta$ positif dan signifikan. Hal ini menunjukan bahwa konsumen telah merasakan dan menilai kemudahan dalam mengoprasikan OVO dan kemudahan dalam bertransaksi sangat baik, 
sehingga membuat konsumen ahirnya berminat menggunakan produk OVO sebagai dompet digital.

3. Variabel keamanan $\left(\mathrm{X}_{3}\right)$ memiliki pengaruh yang positif terhadap minat pemakaian financial technology pada aplikasi OVO. Ini terlihat dari nilai $\beta=0,288$ dengan nilai $t_{\text {hitung }} 3,330$ lebih besar dari nilai tabel $(\alpha=0,05)=1,995$, karena $t_{\text {hitung }}>t_{\text {tabel }}$ maka koefisien $\beta$ positif dan signifikan. Hal ini menunjukan bahwa konsumen telah merasakan dan menilai bahwa sistem keamanan dan keamanan bertransaksi pada aplikasi OVO sangat baik, sehingga membuat konsumen ahirnya berminat menggunakan produk OVO sebagai dompet digital.

4. Variabel manfaat $\left(\mathrm{X}_{1}\right)$, kemudahan $\left(\mathrm{X}_{2}\right)$, dan keamanan $\left(\mathrm{X}_{3}\right)$ secara bersamaan memiliki pengaruh yang positif terhadap minat pemakaian financial technology pada aplikasi OVO. Hal ini manfaat produk yang diberikan OVO, kemudahan dalam mengoprasikan OVO dan kemudahandalam bertransaksi, sistem keamanan dan keamanan bertransaksi pada aplikasi OVO sangat baik, sehingga membuat konsumen ahirnya berminat menggunakan produk

\section{B. Saran} OVO sebagai dompet digital.

Berdasarkan uraian kesimpulan diatas yang didapatkan dalam penelitian ini, maka peneliti mengajukan beberapa saran sebagai berikut :

1. Untuk PT. Visionet Internasional diharapkan untuk terus meningkatkan manfaat, kemudahan dan keamanan OVO itu sendiri, agar para masyarakat lebih antusias dan terus berminat untuk menggunakan OVO pada segala aktivitas keuangan.

2. Untuk aplikasi OVO diharapkan untuk terus meningkatkan peforma aplikasi, agar lebih baik dan lebih lancar ketika digunakan, agar para pengguna semakin mudah dalam menjalankan OVO untuk bertransaksi dalam kegiatan keuangan.

3. Untuk para mahasiswa Fakultas Ekonomi Dan Bisnis Universitas Muhammadiyah Metro, di harapkan untuk tetap antusias memakai OVO sebagai dompet digital, karena OVO menawarkan manfaat, kemudahan dan keamanan yang membuat kesan baik untuk para penggunanya dan sangat membantu dalam melakukan segala aktivitas keuangan para generasi milinieal.

4. Untuk penelitian selanjutnya disarankan untuk menambah variabel independen lainnya selain manfaat, kemudahan dan keamanan yang tentunya dapat mempengaruhi variabel dependen yaitu minat pemakaian financial technology pada aplikasi OVO, supaya melengkapi penelitian ini karena masih ada beberapa variabel independen lain di luar penelitian ini yang mungkin saja berpengaruh pada variabel dependen.

\section{DAFTAR PUSTAKA}

Abdillah, Willy, Jogiyanto (2015), Partical Least Square (PLS) Alternatif Structural Equation Modeling (SEM) dalam penelitian bisnis, yogyakarta:Penerbit Andi.

Abidin, Muhammad Sofyan.2014. "Dampak Kebijakan E-money Di Indonesia Sebagai Alat Sistem Pembayaran Baru." Igarss 2014, no. 1:1-5 https://doi.org/10.1007/s13398-014-0173-7.2. diakses pada tanggal 5 november 2019 pukul 15:30 Wib

Adiyanti (2015) "digital era 4.0".Jakarta.Erlangga vol.55

Anjar priono, 2017. "Analisis pengaruh trust dan risk dalam penerimaan teknology dompet elektronik gopay kota yogjakarta." Universitas islam Indonesia yogyakarta.

Apino. (2017). "Strategi OVO dalam Industry E-money di Indonesia." http://undergruppaper.blogsport.com/2018/strategi-ovo-dalam-industri-e-money-di.html?m=1 diakses pada tanggal 5 november 2019 pukul 15:30 Wib

ARC. alvara reseach center https://dailysocial.id/post/survei-alvara-gojek-layanan-digital-milenial di akses pada tanggal 06/12/2019 pukul 13:29

Bank Indonesia.(2019), Tabel Jumlah Uang Elektronik Beredar. https://www.bi.go.id/id/statistik/sistem-pembayaran/uang-

elektronik/contents/jumlah\%20uang20elektronik.aspx diakses pada tanggal 2 november 2019 pukul 14:05 Wib

107 | Jurnal Akuntansi AKTIVA 
Bachmid, dkk (2016) "manajemen pemasaran jilid 1".Jakarta.Erlangga vol.1210

Cahyo, W. S. 2014. "Pengaruh Persepsi Kebermanfaatan, Keamanan, Kepercayaan dan Persepsi Penggunaan Onlin Banking Pada Mahasiswa S1 Fakultas Ekonomi Universitas Negeri Yogyakarta." Universitas Negeri Yogyakarta

Casalo, et.al(2014) "ekonomi digital".Jakarta.Erlangga vol.79

CNN Indonesia.(2019), Perkembangan Dompet Digital OVO tahun 2019 https://www.CNN.Indonesia/id/statistik/perkembangan-OVO/Dompet-

elektronik/contents/jumlah\%20ovo20e-commers.aspx diakses pada tanggal 5 november 2019 pukul 19:30 Wib

Davis (2010) "digital era 4.0".Jakarta.Erlangga vol.14

Harlan (2014) "digital era 4.0".Jakarta.Erlangga vol.39

Hartono, 2007:166 dalam Shomad dan Purnomosidhi 2012) "ekonomi digital 3.0".Jakarta. Erlangga vol. 132

Heri, P, 1998 "ekonomi digital 3.0".Jakarta. Erlangga vol. 148

Imam Nurmawan, S.E.(2000). "manajemen pemasaran".Jakarta.Erlangga

Iqbaria dalam Amijaya (2010) "digital era 4.0".Jakarta.Erlangga vol.140

Jogiyanto (2007:115) "digital era 4.0".Jakarta.Erlangga vol.79

Johny killis, 1988:26). "ekonomi digital 3.0".Jakarta. Erlangga vol. 109

Kasiram dkk 2008 "Metodologi Penelitian Kualititatif Dan Kuantitatif".Jogjakarta.Penamas vol.149

Kodu (2013) "dasar manajemen pemasaran".Jakarta.Erlangga vol.1252

Kotler Dan Keller.(2008). "Manajemen Pemasaran". Jilid 1 edisi ke 13.Jakarta:Erlangga

Kotler Dan Keller.(2011). "Marketing Manajemen". edisi ke 13.Jakarta:Erlangga vol 6

Leoni joan, Tony sitinjak.(2019) pengaruh persepsi kebermanfaatan dan persepsi kemudahan pengguna terhadap minat penggunakan layanan pembayaran digital go-pay. jurnal manajemen vol: 8,30

Loutung,dkk (2015). "Manajemen Pemasaran".Jakarta.Erlangga

Malau (2017) "strategi manajemen pemasaran jilid 3".Jakarta.Erlangga vol.1252

Muhamad Yuandi (2019) skripsi : Pengaruh Sales Promotion dan Brand Image Terhadap Repurchase Intention Melalui Customer Satisfaction pada Pengguna OVO Surabaya." Surabaya : universitas surabaya.

Muhammad Wildan (2019), Skripsi : Pengaruh Persepsi Kemudahan Penggunaan, Efektivitas Dan Resiko Terhadap Minat Bertransaksi Menggunakan Financial Technology (fintech) (Study Kasus Pada Mahasiswa S1 Febi Uin Walisongo Semarang Angkatan 2014-2018) Semarang : Universitas Islam Negeri Walisongo.

Mulyana (2016) "digital era 4.0".Jakarta.Erlangga vol.208

Nabila Aulia Anwar, yusi tryoni mursityo, retno indah rokhmawati. 2019. Analisis value terhadap minat pengguna OVO di malang raya menggunakan cunsumption value model. Vol. 2 p. 43744375.

Nasir (2005) "Pengertian Populasi Dan Sampel".Jakarta. Erlangga vol.176.

Nuris Nadia Khafiyah (2019), skripsi: Pengaruh Persepsi Mahasiswa Mengenai Uang Elektronik Terhadap Minat Menggunakan aplikasi OVO. Jakarta: universitas islam negeri syarif hidayatullah.

Nazir (2005) "Metode Penyusunan Skripsi".Jakarta.Erlangga vol 176

Nurmalasari, Ajeng (2018), Skripsi: Analisis Minat Penggunaan T-Cash, Pada Mahasiswa Universitas Islam Indonesia, Yogyakarta: Universitas Islam Insonesia.

pratama 2015:197 "Masalah-Masalah Digital".jakarta.Angkasa vol.34

Prof. Dr. Sofyan Assauri, S.E., M.B.A.(2011). "Manajemen Pemasaran Dasar, Konsep Dan Strategi".Jakarta.PT RAJAGRAFINDO PERSADA

Rurie widya rahayu 2018. "Pengaruh Persepsi Kebermanfaatan, persepsi kemudahan, persepsi resiko dan inovasi teknologi Terhadap aplikasi Go pay dari PT Gojek Indonesia study pada masyarakat di kabupaten sleman dan kota yogyakarta." Universitas islam Indonesia yogyakarta.

Tjiptono (2011:2) "prinsip manajemen".Jakarta.Erlangga vol.2

$\mathbf{1 0 8} \mid$ Jurnal Akuntansi AKTIVA 
Tompson dalam Fahmi Nasution (2004) manajemen teknologi. Jakarta.Erlangga vol.12

Turban E., \& King, D., (2002) "digital era 4.0".Jakarta.Erlangga vol.56

Umar (1999) "Metode Penyusunan Skripsi".Jakarta.Erlangga vol 36

Walukow,dkk (2014). "Strategi Manajemen".Jakarta.Erlangga vol.1738

Widiyastuti,K. Handayani,P.\&Wilarsono.L(2017). "Tantangan Dan Hambatan Implementasi Uang Elektronik Indonesia : Study Kasus. PT.XYZ". jurnal sistem keuangan, 13(1), 38-48

Zainul hasan Quthbi 2016. "Pengaruh kemudahan, manfaat, keamanan, dan privasi kecukupan informasi dan ksenangan transaksi terhadap keputusan menggunkan E-money pada bus trans jogja." Bus trans yogyakarta. 